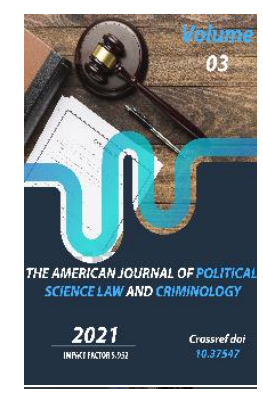

\title{
Customs Related To Tadjiks' Wedding In Jizzakh Oasis
}

Davlatova Khakima

Jizzakh State Pedagogical Institute, Master's Degree Student, Uzbekistan

Journal Website:

http://usajournalshub.c

om/index,php/tajpslc

Copyright: Original

content from this work

may be used under the

terms of the creative

commons attributes

4.0 licence.

\section{ABSTRACT}

In this article, the customs, traditions and ceremonies of tadjiks in Jizzakh oasis are analyzed and compared.

\section{KEYWORDS}

Custom, ritual, wedding, nikah, ceremony, tadjiks, Jizzakh oasis.

\section{INTRODUCTION}

One of the best days of our nation is celebrating a wedding. For this reason, older people always pray and wish: "Let everyone get married and achieve dreams". It is known that, getting married is so important in human life. But is "nikah" necessary to get married? In general, is there any difference between family and nikah? In this regard, we will first focus on the concepts of marriage and family. In uzbek the concept of nikah has got two types of lexical meanings. Nikah (arab. To get married, the union of husband and wife) Ceremony of getting registered marriage via shari'ah, a contract read by the domulla at the ceremony [Explanatory Dictionary of the Uzbek Language, 2006. p. 38]. In short, it is Islamic, religious form of getting married. The Shari'ah regulates family relations and treats marriage 
as a contract based primarily on the obligations and rights of both parties [Islam. Handbook, 1987. P.139-140].

\section{THE MAIN RESULTS AND FINDINGS}

Nowadays, nikah has got two meaning religious and secular. According to secular meaning, a marriage is a legally registered family union with the mutual consent of the spouses; Husband and wife [Explanatory dictionary of the Uzbek language, 2006. p. 38]. In other words, in a secular sense nikah means to register marriage in Civil registry office(CRO). According to Abdurauf Fitrat [Ergasheva $M$, 2003. p. 28], marriage is a union of a man and a woman who want to be a friend in life, a partner in happiness and unhappiness, a companion in times of sorrow and to help each other in happy times, fulfilling their personal and social responsibilities. Marriage is a covenant based on equality and mutual desire between husband and wife, which means sharing life with love and affection. At the same time, marriage is a form of socially approved generational and gender relations, ie the regulation of sexual intercourse and procreation [Socio-psychological and ethical problems, 1989. p.12.].

The word family has got five lexical meanings in Uzbek language. Family is a union of people who are spouses, their children and close relatives; household [Explanatory Dictionary of the Uzbek Language, 2006. p. 97]. Its other meanings are close to each other, and can be said to be groups of people, peoples, countries, or plants and animals, brothers and sisters, united in a common sense. Besides, it means in a dictionary wife in colloquial language. [Explanatory Dictionary of the Uzbek Language, 2006. p. 97]. In the encyclopedia "Islam" [Islam. Encyclopedia,
2003. p. 313] unlike marriage, there is no information about the concept of family. Generally, family is a group based on nikah.

In the Tajiks of the Jizzakh oasis we are studying, the concepts of "marriage" and "family" are similar in content and form to the above ideas, but in their reflection in social life, rituals, customs and traditions have certain peculiarities.

Customs and ceremonies of Jizzakh oasis are treasure which is not known yet. their national customs, wedding ceremonies, food, clothing and jewelry, national games and so on is related to the natural geographical location, language, economy, lifestyle of the population of each region.

Coming from above, we would like to draw your attention to the wedding ceremonies of the Forish Tajiks, the densest Tajiks in the Jizzakh oasis. Until the middle of the twentieth century, the weddings and feasts of the Forish Tajiks were held in the old style. People sat around the fire, two or three people took turns singing, and poets sang muhammas. Each village had its own hafiz and poets, and in the past Zokir-hafiz, Firoqi and master Qudriddin Sintabi, Berdikhan hafiz were considered to be the best hafiz and poets of the Forish Tajiks.

The wedding party was traditionally held mainly in the evening. During the day there was a race, wrestling and kupkari. Then, before the feast began, the bridegroom's neighbors entertained the guests from afar. The owner of the house is responsible for feeding and sleeping of the guest and his donkey (horse, donkey). In the absence of community canteens and hotels, this was considered one of the best habits of the mountain people. 
The marriage took place on several stages with the permission and bless of the parents. Unlike in other parts of the country, the Forish Tajiks began to look for a girl who would suit them before the boy grew up. From the moment a girl is found, the boy's aunts or uncles enter the girl's house under the pretext of seeing her, her parents and, perhaps, the bride's situation at home. Then neighbors and acquaintances ask about the family of the chosen girl. In case of a positive answer, the matchmakers are sent home. The matchmakers mark the day of the Engagement - "Fatiha". On this day, the wellknown elders of the neighborhood, the elder of the Mahallya, gather at the girl's house. The "bread-breaking" ceremony begins after the matchmakers have announced their intention to come.

From this point on, young people are considered to be connected and engaged. The Fatiha wedding ends with the appointment of the date of the nikah and wedding, taking into account the age of the two parties. A few days before the wedding, ina girl's house "girl's palov" ceremony will be held, which the girl invites her relatives and friends [Mahmudi Farishi. 2000].

Xoni dodosh huy-ho'yo,

Xoni baxtash bismillo.

Kelin omad bismillo,

Ba sarash toji tillo[Sharipov A. 2020 y].

After the wedding ceremony, the imam of the mosque recites the "Khutbai nikoh" for bride and groom, after which they are declared husband and wife before God. Imam explains the rights and obligations of husband and wife. Before sending bride to groom's house, farewell party is held. Relatives and close friends go with bride. They sing songs( "Olan" and "Yor-yor"). Wedding party is also held in groom's side. A real wedding begins with welcoming the bride to the groom's house. After the wedding, the "Kelin Salom" ceremony will begin in the morning. The groom's parents, all close relatives and close neighbors gather in the yard near the beginning of the ceremony. All of them, in turn, come to the bride and offer their wishes, gifts and blesses. The bride has to bow down and greet everyone. In this way the holiday is over and family life begins.

\section{CONCLUSION}

From the above, it can be concluded that as a result of the historical development of each nation, its living conditions, environment, cooperation, national marriage-related ceremonies, customs and traditions have emerged. Our people do not approve of men and women living together without marriage because they believe in Islam. As Uzbeks, in Tajiks marriage is valued both as an obligation and as a national value. There are moral, medical, legal and other reasons for this.

\section{REFERENCES}

1. Mahmudi Farishi. Tajikoni Farish. Gulistan, 2000.

2. Nikah/ Islam. Directory / Usmonov M.A. under the editorship - Tashkent: Uzbek Soviet Encyclopedia Editor-in-Chief, 1987. 2nd edition. - p. 139-140.

3. Marriage / Explanatory dictionary of the Uzbek language: more than 80,000 words and phrases. J. III. N - Order / Editorial Board: t., Mirzaev (leader) and head. - Tashkent: "National Encyclopedia of Uzbekistan" State Science. ed., 2006. - p. 38. 
4. Family / Islam. Encyclopedia: A-H / Z. Edited by Husniddinov. ost. - Tashkent: "National Encyclopedia of Uzbekistan" State Scientific Publishing House, 2003. - p. 313.

5. Семья. Социально-психологические и этические проблемы: Справочник / Рук. авт. кол. В.И. Зацепин. - Киев: Политиздат, 1989. - С. 12.

6. Sharipov A. Farish: People and rituals. Samarkand, "Turon-nashr” 2020.

7. Ergasheva M. Nikah and family issues in Fitrat heritage// legally protected. Tashkent 2003. - № 4 (88). -p. 28.

8. Meliev, U., \& Nematov, O. SUFI ALLAYAR. Zbiór artykułów naukowych recenzowanych., 80.

9. Nematov, O. (2020). CRYPTOGRAPHICAL METHODS OF INFORMATION PROTECTION. DEVELOPMENT STEPS OF CRYPTOGRAPHY. In Молодой исследователь: вызовы и перспективы (рр. 355-361).

10. Курбанова, Д. А. (2015). Об истории прикладного искусства Узбекистана XIX столетия и о предметах Государственного музея искусства народов Востока Российской Федерации. Молодой ученый, (10), 1513-1515.

11. Baltabaeva, M. M. (2021). Women's Problem At A New Stage Of SocioEconomic And Political Change In Uzbekistan: Problems And Solutions. The American Journal of Social Science and Education Innovations, 3(01), 314318.

12. Балтабаева, М. М. (2019). МЕСТО МАЛОГО БИЗНЕСА И ПРЕДПРИНИМАТЕЛЬСТВА В
РАЗВИТИИ ПРОМЫШЛЕННОСТИ И СЕЛЬСКОГО ХОЗЯЙСТВА РЕСПУБЛИКИ УЗБЕКИСТАН РLAСЕ ОF SMALL BUSINESS AND ENTREPRENEURSHIP IN THE DEVELOPMENT OF INDUSTRY AND AGRICULTURE. CИHTEЗ HAУKИ И ОБЩЕСТВА В РЕШЕНИИ ГЛОБАЛЬНЫХ ПРОБЛЕМ, 52.

13. Nazarov, A. Y. (2021, February). Classification of Documents of Turkestan Scientific Societies Kept In The National Archive Of Uzbekistan. In INTERNATIONAL SCIENTIFIC AND CURRENT RESEARCH CONFERENCES (pp. 9-12).

14. Go'dalov, M. R. (2014). Nature of Jizzakh region and its protection.-T.:“. Science and technology.

15. Juraev, Z. M., \& Masalieva, O. M. (2020). Eleven Ahmad Pilgrimage And Seal And Flag Of Victory. The American Journal of Social Science and Education Innovations, 2(12), 43-50.

16. МАСАЛИЕВА, О. М. (2021). АКАДЕМИК АР МУХАММАДЖОНОВНИНГ БУХОРО ХОНЛИГИ МАНБАШУНОСЛИГИГА ҚЎШГАН ХИССАСИ. In Uzbek Conference Publishing Hub (Vol. 1, No. 01, pp. 28-34).

17. Masalievna, M. O. (2017). LOCAL HISTORIOGRAPHY OF BUKHARA EMIRATE AT THE END OF NINETEENTH AND EARLY TWENTIETH CENTURIES. Himalayan and Central Asian Studies, 21(4), 39. 